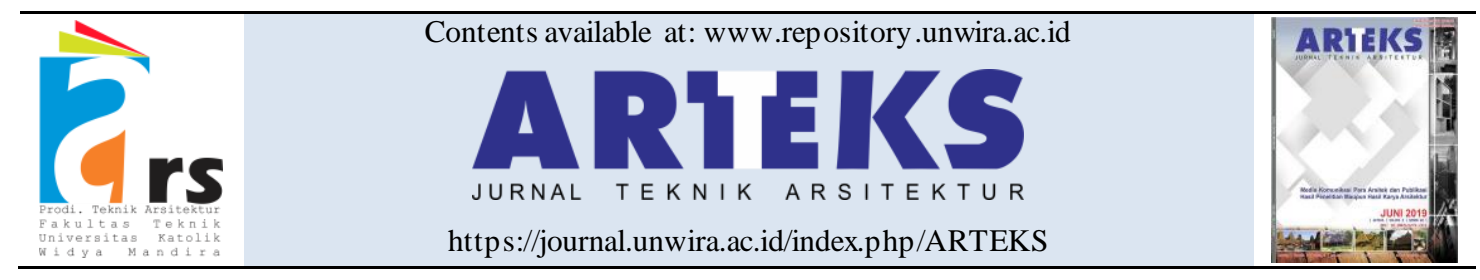

Research paper

doi: 10.30822/arteks.v6i1.644

\title{
Ethnomodelling on Atag construction in Ajung Village, Jember Regency
}

\author{
Yusfan Adeputera Yusran ${ }^{*}$ (D), Sri Utami², Surjono ${ }^{3}$ (D), Atsar Yaisy Muhammad \\ 1,2,4 Department of Architecture, Universitas Brawijaya \\ ${ }^{3}$ Urban and Regional Planning Department, Universitas Brawijaya \\ Jl. MT. Haryono, no. 167, Malang, Indonesia

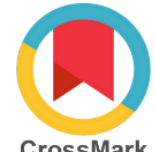

\begin{tabular}{|c|c|}
\hline ARTICLE INFO & ABSTRACT \\
\hline $\begin{array}{l}\text { Article history: } \\
\text { Received July } 29,2020 \\
\text { Received in revised form August } 31 \text {, } \\
2020 \\
\text { Accepted September } 10,2020 \\
\text { Available online April } 01,2021\end{array}$ & $\begin{array}{l}\text { Atag functions as a place for the air curing process to dry tobacco } \\
\text { leaves. This building, which is made of bamboo, has existed in } \\
\text { Indonesia since } 1850 \text { and used to produce authentic quality cigars. } \\
\text { Initially, this building was only utilized for local materials, however, } \\
\text { based on the shape, dimensions, and construction, there is a } \\
\text { tendency for Atag to be established by considering several technical }\end{array}$ \\
\hline $\begin{array}{l}\text { Keywords: } \\
\text { Ethnomodelling } \\
\text { Local intelligence } \\
\text { Tobacco warehouse }\end{array}$ & $\begin{array}{l}\text { aspects. Therefore, this study aims to examine the technical ideas, } \\
\text { such as calculations, practices, and procedures for making Atag } \\
\text { using the ethnomodelling strategy. The results showed that the } \\
\text { community's practices and calculations in building Atag were a } \\
\text { logical response in adapting to natural conditions such as climate, } \\
\text { wind, and humidity. It also provided intelligence in utilizing the } \\
\text { potential of local materials such as bamboo and sugarcane leaves. }\end{array}$ \\
\hline $\begin{array}{l}\text { *Corresponding author: Yusfan Adeputera } \\
\text { Yusran } \\
\text { Department of Architecture, Universitas } \\
\text { Brawijaya, Indonesia } \\
\text { Email: yusfan @ub.ac.id } \\
\text { ORCID: https://orcid.org/0000-0002-2082- } \\
9153\end{array}$ & \\
\hline
\end{tabular}

\section{Introduction}

Indonesia is known as the fifth largest producer of tobacco in the world. One of the significant types dominating the country is the Besuki Na Oogst (BNO), mostly produced from agricultural land in Jember Regency (Pratama, Soetriono, and Januar 2018). In the cigar industry process, a special building known as Atag is needed to carry out the air curing process for drying tobacco leaves in Jember Regency. The drying stage uses passive ventilation by optimizing the openings on each side of the building. Atag consists of bamboo columns and beams called galang, placed across the building to hang the dolok. According to studies, a dolok comprises of an STG (Sunduk Tali Goni) or gunny rope in the form of tobacco leaves that have gone through the stabbing process. The construction and materials used are adjusted to the needs of its function, such as the leaves' drying process.

Ethnomodelling is a study of the mathematical phenomena in local culture using three knowledge fields, namely modeling, cultural knowledge, and ethnomathematic. Although this study was built using the principles of local wisdom, Atag is believed to possess the right knowledge base in the drying process. This study aims to understand Atag's construction using the ethnomodelling perspective, in order to obtain a complete description related to the skills, technology, and mathematical practices applied to its constructions. The results of this study are 
essential to determine the relationship between local cultural and modern scientific knowledge.

\section{Ethnomodelling study}

Ethnomodelling is a study of mathematical practice towards community groups' strategies and used to solve daily life problems through modeling (Orey and Rosa 2010; Rosa and Orey 2013). Most of the local knowledge developed by community groups are usually based on intuition and closely related to local culture. Therefore, studies on ethnomodelling are used to prove that the diversity and sophistication of mathematical practice in objects made by local communities have a strong foundation in popular scientific understanding, such as geometric shapes in crafts, architecture, and indigenous practice cultural artifacts. According to Eglash et al. (2006), most of these concepts are in the form of numerical relationships such as measuring, calculating, predicting, navigating, modeling, and several other mathematical procedures (Eglash et al. 2006).

According to Rosa and Orey (2010), ethnomodelling is the intersection of cultural anthropology, ethnomathematics, and mathematical modeling as shown in figure 1. It is related to the use of local mathematical knowledge to solve problems; therefore, it can be proven scientifically (Rosa and Orey 2011; 2016; Rosa et al. 2016). Mathematical modeling is a tool, model, or formula used to observe mathematical practice. Meanwhile, cultural anthropology is related to the "translation" between cultural (emic) and academic (ethical) perspectives (Eglash et al. 2006; Rosa and Orey 2019). The relationship between these three studies forms a part of ethnomodelling studies.

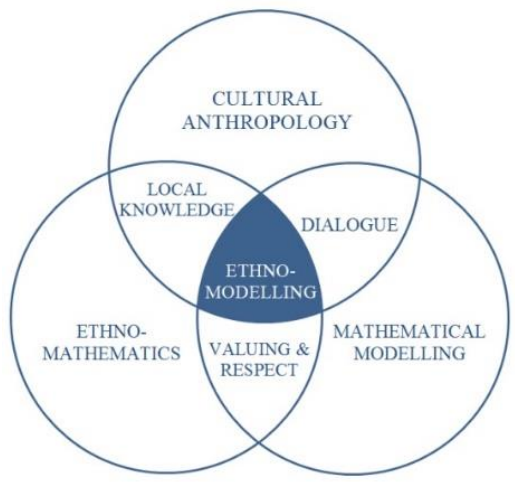

Figure 1. Ethnomodelling is the intersection of three fields of study

Source: (Rosa and Orey 2018)

\section{Method}

This research carried out the observation method at the Atag warehouse in Ajung Village, Jember Regency. In addition, the results of the observations in the form of measurements, initial sketches, and photo documentation were processed and descriptively translated for further analysis. Redrawing is carried out digitally following the data obtained in the field, to facilitate structures and construction systems identification at the Atag.

The interviews results with warehouse leaders in the Ajung area and workers with an adequate understanding of the leaf drying process at Atag were used to strengthen the analysis. Furthermore, the redrawing model design was cross-checked with the interview results to obtain emic knowledge from Atag warehouse. The model is further cross-checked with scientific, mathematical knowledge to obtain ethical knowledge. The results of the emic and ethics observations are then related to cultural aspects that develop in the local community lives, such as the wisdom aspects of architecture.

\section{Result and discussion}

Titien Saraswati (2008) identified Los, an Ataglike building located in Klaten, as one of the vernacular buildings with unique materials, construction technology, and shapes that can optimize the tobacco leaves' drying process. Furthermore, the uniqueness of the Los buildings determines the quality of the tobacco leaves produced. According to Titien Saraswati (2008) and Tirtosastro and Murdiyati (2011), Los vernacular values illustrate the strategies used by the surrounding community to optimize local materials that are adaptive and friendly to the environment. However, this research did not investigate the unique form of the building from the ethnomodel perspective.

\section{Atag description}

Atag warehouse is a building that functions as a place for air curing or drying tobacco. Air curing is a process that aims to reduce water content in the leaves while maintaining its integrity with a closed drying area used to prevent direct sunlight. Therefore, Atag is made to maintain the humidity and drying temperature of tobacco leaves. In 
Ajung Village, this process is characterized by using organic materials such as bamboo and sugarcane leaves on walls and roofs. The frame structure also uses bamboo consisting of poles and beams, which acts as a place to hang tobacco leaves. The Bambusa Blumeana is the suitable bamboo used as a frame with a lifespan of three to four years, obtained from the surrounding environment. This bamboo is also known as thorny bamboo or pring ori by the local community.

Atag warehouse is square with gable construction, as shown in figures 2 to 7. In Ajung Village, it is generally 18, 64, and 12.5 meters in width, length, and height. (provision for Perkebunan Nusantara X Company). The interior is mostly used for drying tobacco leaves, and there is no barrier separating the space in the building. Furthermore, it consists of 30 air chambers with a width of two meters per module used for drying tobacco leaves that have gone through the sorting and raft stabbing process. Tobacco is hung in the supporting beam at the wind chamber and circulated at the building's side and center to facilitate the drying process.

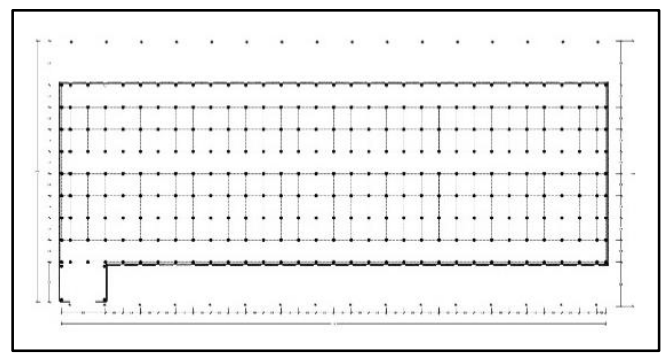

Figure 2. Atag warehouse plan

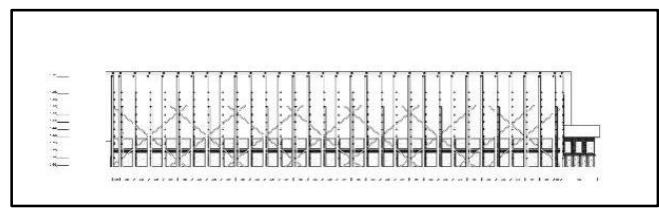

Figure 3. Atag warehouse longitudinal cut

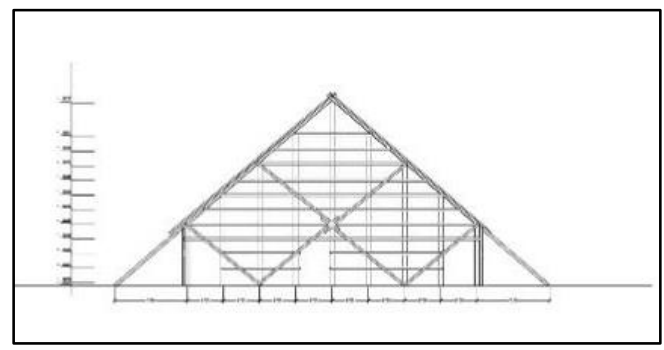

Figure 4. Atag warehouse cross-section

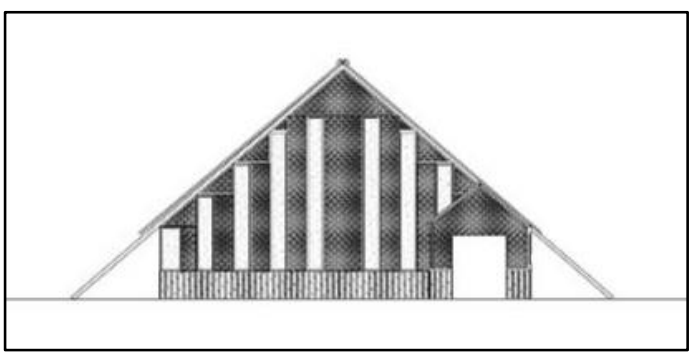

Figure 5. Front view of Atag warehouse

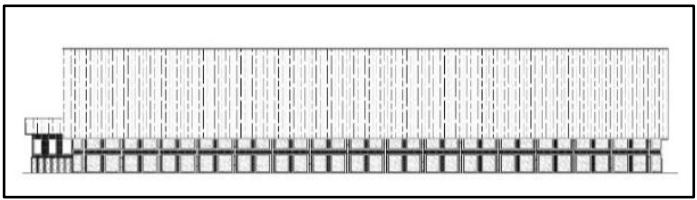

Figure 6. Side view of Atag warehouse

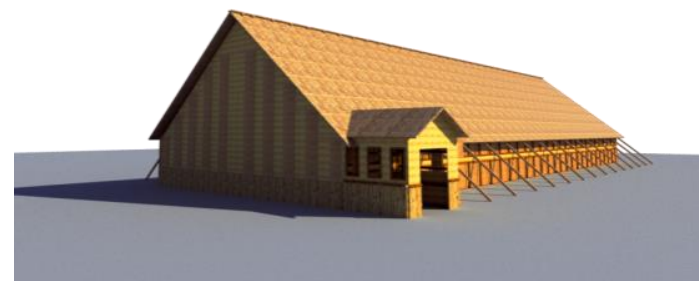

Figure 7. Atag warehouse perspective

The Atag warehouse construction cons is ts of a roof, body frame, and a foundation covered by a wall, as shown in figures 8, 9, 10 and 11 . The roof truss is a system with the body frame in the form of purlins. Meanwhile, the roof covering is in the form of dried sugarcane leaves (blabad) tied with bamboo ropes (tutus/gutos). Blabad is tied to purlins or chunks of bamboo to be strong against the wind. This material is easy to obtain due to the large number of sugarcane plantations around Atag.

The height of the warehouse is adjusted to the length of the bamboo, without connection. Therefore, the bamboo used as a center pole can support the upperstructure and properly carry the load. This is because most of the covers of the purlins system are in the form of canal from the roof, namely blabad, which is assisted by additional coatings in bamboo, blabad, and gunny sack and plastic found in some Atags. Furthermore, there are also openings used to adjust the temperature and humidity. A pedestal supports the lower structure in the form of stone or concrete, which is partially planted above the ground. While the floor is in the form of compacted soil without any pavement or backfill. 


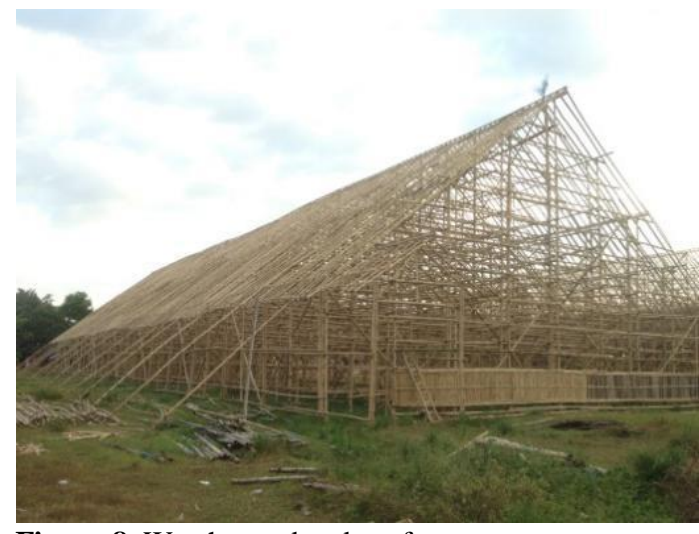

Figure 8. Warehouse bamboo frame

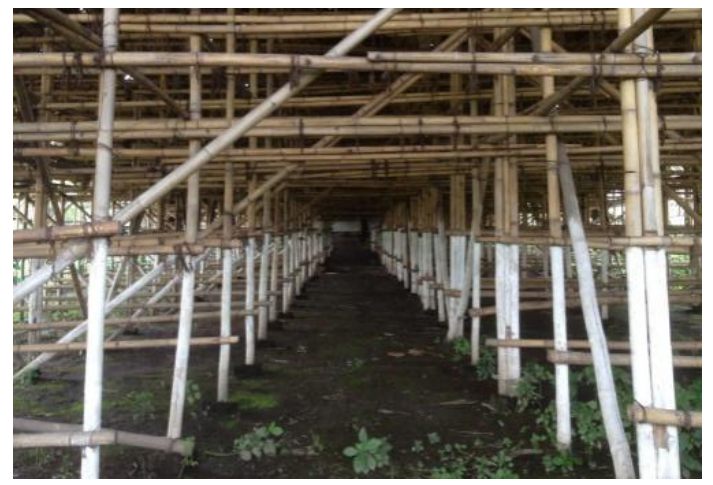

Figure 9. Warehouse floor and foundation

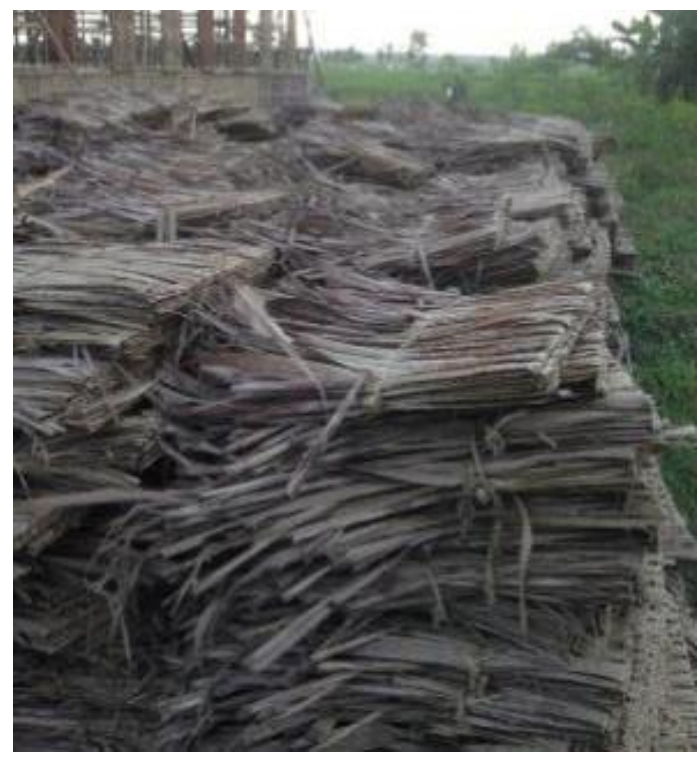

Figure 10. Roof cover from sugar cane leaves (blabad)

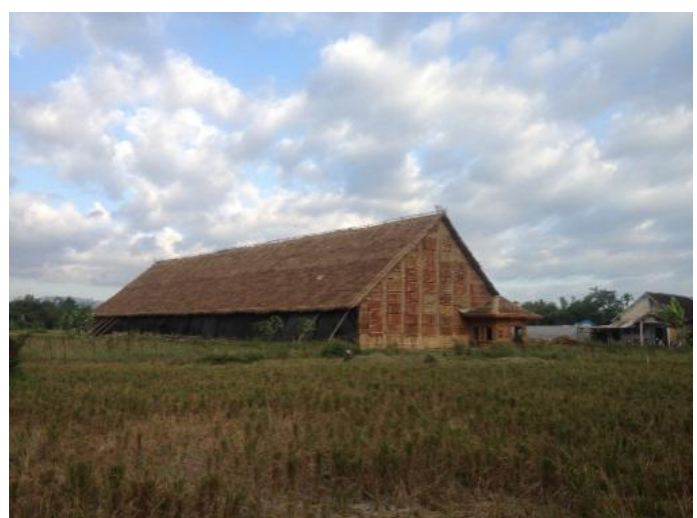

Figure 11. A ready Atag warehouse
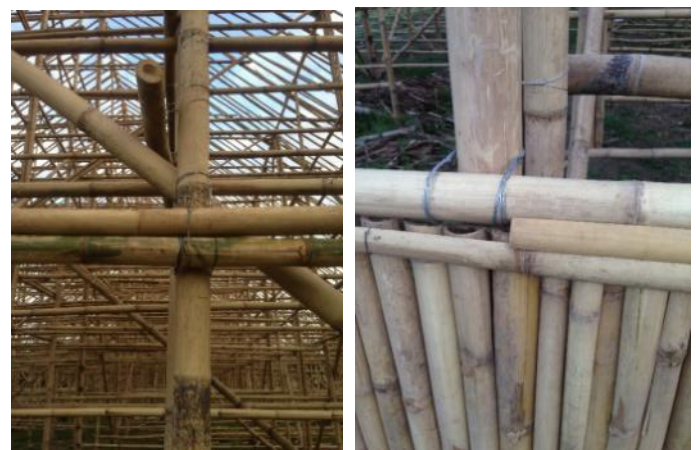

Figure 12. Column and pole wire connection

The Atag frame structure in Ajung Village is made of bamboo tied using 16 galvanized wire rope or used tires, as shown in figure 12. The frame consists of bamboo, which forms a conventional triangular roof truss construction. Each of these construction forms a wind chamber that is used to hang tobacco leaves. In one building, there are thirty wind chambers with two types of frames. The first is a truncated triangle construction, while the second is a complete triangle construction with the addition of continuous diagonal bamboo from the roof as a stiffener, as shown in figure 13.

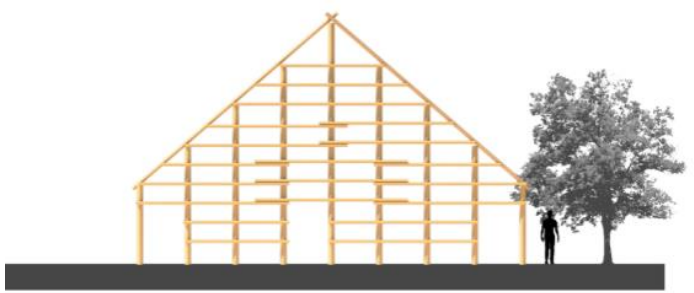




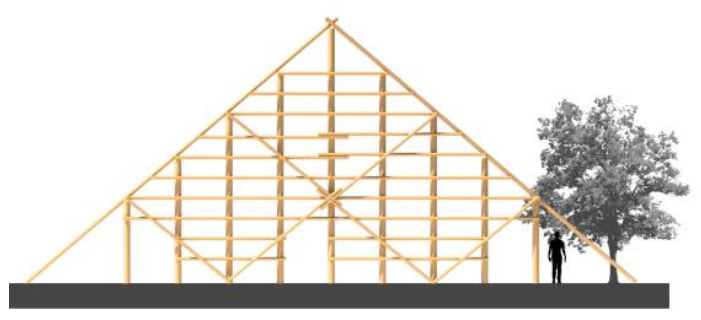

Figure 13. Warehouse frames without (top) and with (bottom) supports

These two frames are arranged alternately with the distance between the modules at two meters wide, thereby forming a wind chamber. The frames are tied with crossed bamboos and reinforced by the presence of purlins.

\section{Cultural knowledge from Atag}

The process of building Atag

Atag's construction stage starts with drying bamboo as the main material, as shown in figure 14. The bamboo is then assembled to form a truncated triangular geometric frame (type 1) consisting of 9 poles and connected by a transverse bamboo rod called the galang (the place to hang the dolok). This is further strengthened by the bamboo frame's cross ties that resemble the $\mathrm{V}$ and $\mathrm{W}$ letters. After completing this frame, a subsequent similar triangular geometrical frame is constructed that is supported and alternated with modules spacing per two meters. Furthermore, two bamboo culms are mounted across the third and seventh posts to tie each triangular frame module and also join each of the four frame areas. The process is repeated until a total of 33 frame modules are standing. This is followed by the installation of the purlins frame to strengthen the bonds between modules as well as a place to tie blabad (sugar cane roof). Finally, the building cover is installed with a gedek or gunny sack.
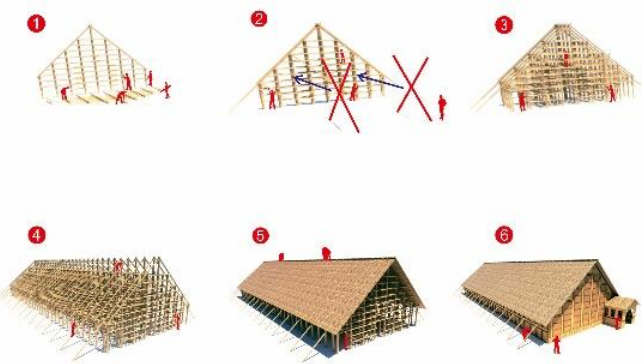

Figure 14. Atag construction illustration
The process of hanging tobacco leaves

Tobacco leaves can be harvested from the $45^{\text {th }}$ to $95^{\text {th }}$ days after planting according to the type and technique utilized. The plucked leaves need to be immediately sewn with gunny rope (sujen), then tied to the dolok, and hung to the galang. This process allows for the immediate circulation of good air for the drying process, as shown in figures 15 and 16. The speed used to arrange the leaves acts as the determinant because they tend to experience respiration, which accelerates the leaf rot quickly.

In addition, the leaf extract is assembled per STG, and the size is approximately 30 to 40 . Subsequently, each leaf is hung five meters apart because the tight spacing can make the leaf color darker and potentially damaged or rot. Furthermore, the STGs were hung on the dolok, as shown in figure 16. Usually, one box contains three and four STGs for large and small leaves, respectively. The distance of each STG on the dolok is 15 to 20 centimeters.
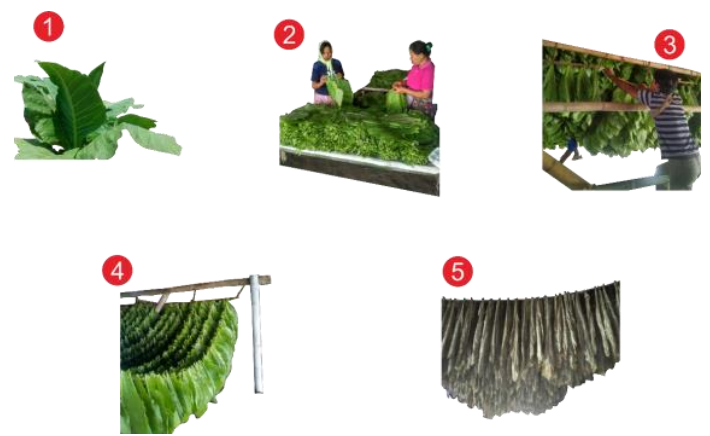

Figure 15. The process of hanging leaves

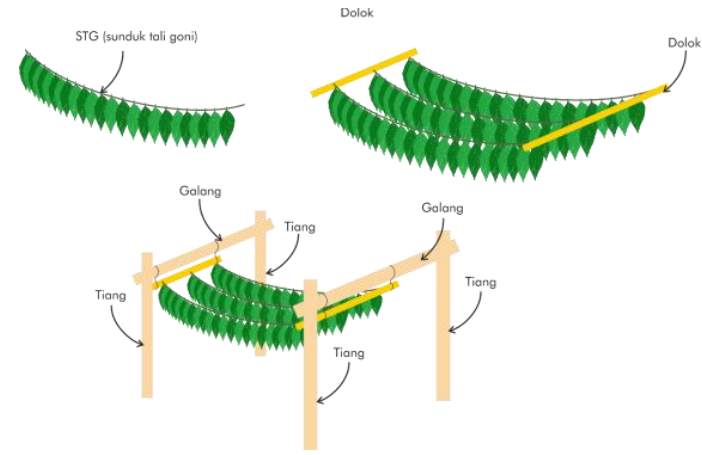

Figure 16. Illustration of hanging tobacco

After the leaves are neatly strung together in the STG shape, it is attached to the dolok and then hung in the galang on the Atag construction. This hanging room is called the wind chamber, and each consists of one class or type of leaf, in order 
to facilitate the treatment and calculation of the drying process. Apart from the wind chamber, there is also an air circulation room beside and in the middle of the warehouse at a distance of 2.5 meters.

\section{Ethical knowledge at Atag}

The ethical approach is considered a description and analysis of concepts, practices, and procedures expressed in the form of a conceptual schema by scientific observers (Rosa and Orey 2018). This approach complements and validates emic knowledge in order to prove that local people's knowledge rooted in cultural habits is also rational (Kloos 2000; Khondker 2004; Ambrosio 2006). The description of this knowledge is essential in order to maintain the use of locality values in solving daily life problems, especially in optimizing natural conditions and the potential of local communities.

Citraningrum and Herawati (2020) stated that the elements in Atag affect the smoothness of the air curing process. This is because the shape is proven to keep the temperature and micro humidity consistent, irrespective of the fact that the external macro temperature conditions fluctuate. In addition, there is the possible occurrence of airflow systems with cross ventilation because Atag has dimensions that match the conditions for cross ventilation, namely $\mathrm{W} \leq 5 \mathrm{H}$ for buildings located in tropical areas.

$\mathrm{W}($ Atag wide $)=20 \mathrm{~m}$ $\mathrm{H}($ Atag height $)=12,5 \mathrm{~m}$

Conditions for cross ventilation $\rightarrow \mathrm{W} \leq 5 \mathrm{H}$

$$
\begin{aligned}
& =20 \leq 5(12,5) \\
& =20 \leq 62,5
\end{aligned}
$$

Therefore, based on these calculations, the Atag shape can optimize airflow using the concept of cross-ventilation, as shown in figure 17. According to Citraningrum and Herawati (2020), the porous cover material, window openings on all sides of the building, presence of wind chambers, and the building's height make an excellent air curing process.

The majority of the Atags in Ajung Village have a building orientation that stretches northsouth, which evenly exposes the roof area to sunlight in the morning and evening. Furthermore, the orientation of environmental conditions such as land area, trees, and distance from other buildings can affect the warehouse's humidity. This is one of the reasons the majority of the Atags are located in the middle of paddy fields.

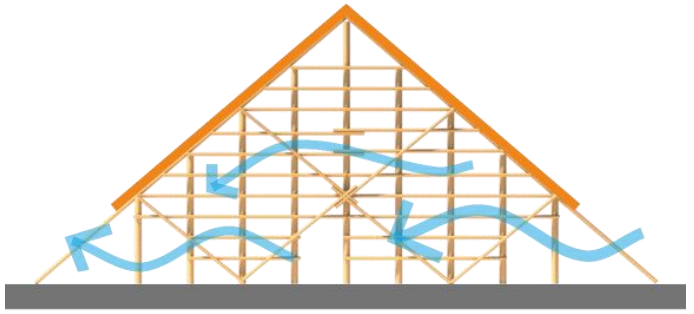

Figure 17. Cross ventilation on Atag

In terms of its construction, trusses are used as load-bearing structures with the main principle of assembling all elements into a triangle because it is the most stable geometric shape. Furthermore, in triangular shapes, the deformation is small and related to trunk length changes due to the force caused by external loads, as shown in figure 18 . The angle formed between the two trunk does not change in a triangle because of the stable shape shown in figure 19.

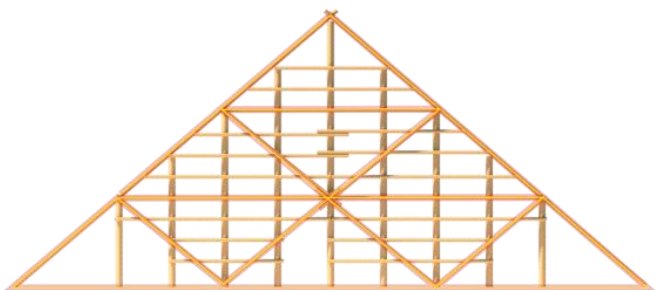

Figure 18. The triangular element in the Atag construction

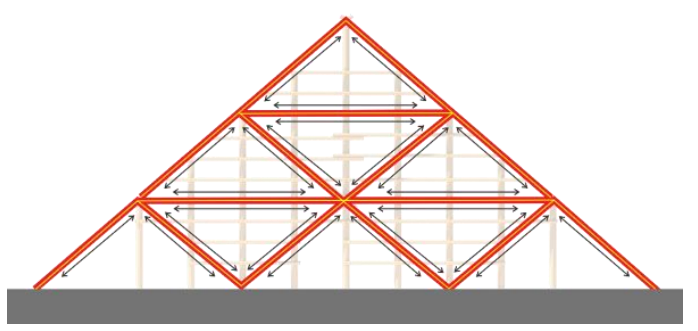

Figure 19. The sty les distribution on the Atag

Ethnomathematics description in Atag warehouse According to Borba (in Supiyati, Hanum, and Jailani 2019), ethnomathematics is a human method of using certain cultures in mathematical concepts when dealing with relational and spatial aspects of their lives. In addition, Rosa and Orey (2016) defined ethnomathematics as applying mathematical skills, ideas, procedures, and practices applied in the past by members of certain cultural groups in different contexts. Ethnomathematics emerged as a new category in 
the conceptualdiscourse, the interaction between mathematics and culture, or a complex and dynamic representation that illustrates the influence of cultural use in its mathematical application.

When viewed from the ethnomathematics aspect, the Atag frame forms a triangular shape with a base length of 30 meters (frame type 2) and a height of 12.5 meters, with a pitagoras used to form an oblique side of 19.53 meters. Therefore, a roof slope angle of $39.8^{\circ}$ was obtained, as shown in figure 20. This size consideration is ethically supported by the maximum height of the Atag, which is determined from the optimal length of the bamboo thorn used as a pole construction, by 12.5 meters. The roof sloping beam (rafters) can also be supported directly by bamboo thorns that grow up to 18-21.5 meters (Sutardi 2015).

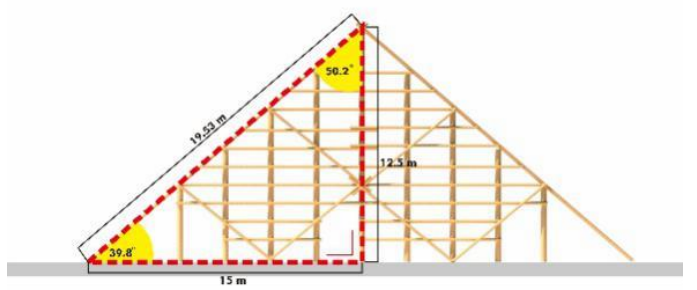

Figure 20. Atag roof slope angle

The analysis results shows that the most ideal slope is optimized at an angle of $39.8^{\circ}$ in the Atag, which also acts as a consideration to prevent rainwater from entering the building due to the blabad (sugarcane leaves). When the angle is more than $40^{\circ}$, the wind chamber area is reduced, therefore making the drying area smaller. The slope of $40^{\circ}$ acts as a form of local community intelligence in optimizing the Atag function, which is responsive to the surrounding climatic conditions.

The Atag consists of the dolok and galang, which function as a place for hanging tobacco leaves and a local community's intelligence phenomenon. The distance of each galang, which is approximately one meter, is an adjustment to the length of the tobacco leaves in order to provide optimal air circulation space in the drying process. The formula for the distance of each galang is obtained by comparing the size of the tobacco leaf with the required circulation distance as shown in figure 21. This is adjusted to the drying process's needs to obtain a circulation flow that can ease the temperature and humidity conditioning in Atag.
Tobacco leaves have dimensions of $50-60 \mathrm{~cm}$ long and $30-40 \mathrm{~cm}$ wide. This measure is used to determine each galang's distance, which is $2 \mathrm{x}$, with $\mathrm{x}$ representing the tobacco leaf's length. Meanwhile, each warehouse column's size is determined by 6y where y represents the width of tobacco leaves with suitable temperature and humidity needed to produce the needed quality. The higher humidity of the soil surface makes it necessary to hang the leaves far from the ground to prevent it from rotting quickly. Therefore, tobacco leaf hanging is determined at a distance of 4x, which enables Atag to optimize the space capable of fulfilling the hanging needs, thereby optimizing the air curing process.

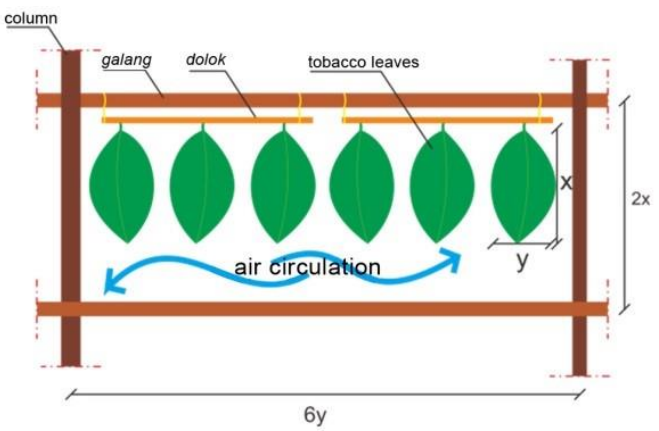

Figure 21. How to determine the size in the tobacco leaf hanging process

The interest in deepening and understanding the phenomena that occur at Atag is not only at the cultural knowledge level, rather it can also be carried out in the realm of theoretical understanding because the visible physical phenomenon is full of meaning and tightly stored behind its physical phenomena in the form of ineffable knowledge (Subroto 2019). According to Lloyd (2011), research on this practice can be considered a form of resistance to academic knowledge imposition, with creative and innovative steps taken to be adaptive to local challenges.

\section{Conclusion}

In conclusion, the Atag warehouse is characterized by a vernacular building using distinctive practices in the materials, shapes, and construction systems. Furthermore, the skills, technology, and practices developed by local communities at Atag are still being used to fulfill the tobacco leaf industry's demands in Jember 
Regency. The three research results associated with the ethnomodelling approach to Atag construction, which is closely related to the habit of making Atags in Ajung Village, is the result of community intelligence in optimizing the surrounding potential. Irrespective of the traditional production of Atags, the construction form is needed to assist in the proper drying process of tobacco leaves. The material used from the surrounding environment is then assembled into a construction according to the needs and conditions. Furthermore, the material availability aspect is considered mathematically optimized in the construction, spatial, and relational aspects in its construction. The use of the ethnomathematics process in calculating the analysis showed that the treatment in the drying process is carried out by considering the roof angle capable of optimizing space as well as rain response, internal air circulation, efficiency, and effectiveness of the tobacco drying process.

\section{References}

Ambrosio, Ubiratan D. 2006. 'The Program Ethnomathematics and the Challenges of Globalization'. Circumscribere: International Journal for the History of Science 1 (1): 74 82.

https://revistas.pucsp.br/index.php/circumhc/ article/view/552/1007.

Citraningrum, Andika, and Daning Herawati. 2020. 'Lesson from Vernacular Tobacco Barn: A Passive Design Strategy for EnergyIndependent Building'. In Proceedings of the International Conference of Heritage \& Culture in Integrated, 195:78-85. Atlantis Press.

https://doi.org/10.2991/aer.k.200729.013.

Eglash, Ron, Audrey Bennett, Casey O’donnell, Sybillyn Jennings, and Margaret Cintorino. 2006. 'Culturally Situated Design Tools: Ethnocomputing from Field Site to Classroom'. American Anthropologist 108 (2): 347-62. https://doi.org/10.1525/aa.2006.108.2.347.

Khondker, Habibul. 2004. 'Glocalization as Globalization: Evolution of a Sociological Concept'. Bangladesh E-Journal of Sociology 1

(2):

1-9.
http://www.bangladeshsociology.org/Habib ejournal Paper GlobalizationHHK, PDF.pdf.

Kloos, P. 2000. 'The Dialectics of Globalization and Localization'. In The Ends of Globalization: Bringing Society Back In, edited by Don Kalb, Marco van der Land, Richard Staring, Bart Van Steenbergen, and Nico Wilterdink, 281-98. Lanham, Maryland, London: Rowman \& Littlefield Publishers.

Lloyd, Jon C. 2011. 'For Clues to HAI Prevention, Seek out Positive Deviance'. Healthcare Purchasing News, January 2011. https://cdn.hpnonline.com/inside/201101/1101-PnP.html.

Orey, Daniel Clark, and Milton Rosa. 2010. 'Ethnomodeling: A Pedagogical Action for Uncovering Ethnomathematical Practices.' Journal of Mathematical Modelling and Application $\quad 1 \quad$ (3): 58-67. https://proxy.furb.br/ojs/index.php/modelling /article/view/1972/1469.

Pratama, AnggiLian Yustin, Soetriono Soetriono, and Jani Januar. 2018. 'The Farm Risk Management of Besuki Naoogst Tobacco in Tanjungrejo Village, Jember Regency'. Agricultural Social Economic Journal 18 (1): 13-22.

https ://doi.org/10.21776/ub.agrise.2018.018.1 .3.

Rosa, Milton, Ubiratan D'Ambrosio, Daniel Clark Orey, Lawrence Shirley, Wilfredo V. Alangui, Pedro Palhares, and Maria Elena Gavarrete. 2016. Current and Future Perspectives of Ethnomathematics as a Program. ICME-13 Topical Surveys. Cham: Springer International Publishing. https://doi.org/10.1007/978-3-319-30120-4.

Rosa, Milton, and Daniel Orey. 2016. 'Humanizing Mathematics through Ethnomodelling'. Journal of Humanistic Mathematics $6 \quad$ (2): $3-22$. https://doi.org/10.5642/jhummath.201602.03.

Rosa, Milton, and Daniel Clark Orey. 2011. 'Ethnomathematics : The Cultural Aspects of Mathematics Etnomatemática: Os Aspectos Culturais Da Matemática'. Revista Latinoamericana de Etnomatemática 4 (2): 32-54. https://revista.etnomatematica.org/index.php/ RevLatEm/article/view/32.

- 2013. 'Ethnomodelling as a Research Lens on Ethnomathematics and Modelling'. International Perspectives on the Teaching and Learning of Mathematical Modelling 6 
(2): 117-27. https://doi.org/10.1007/978-94007-6540-5_10.

. 2018. 'The Anthropological Dimension on Ethnomodelling Research Based on Ethnomathematics and Modelling'. Open Access Journal of Archaeology \& Anthropology 1 (1). https://doi.org/10.33552/OAJAA.2018.01.00 0503 .

. 2019. 'Ethnomathematics and the Responsible Subversion of Its Pedagogical Action: An Investigation Based on Three Anthropological Approaches'. Revista Brasileira de Estudos Pedagógicos 100 (254). https://doi.org/10.24109/21766681.rbep.100i254.3939.

Subroto, Tarcicius Yoyok Wahyu. 2019. 'Koeksistensi Alam Dan Budaya Dalam Arsitektur'. ARTEKS: Jurnal Teknik Arsitektur 3 (2). https://doi.org/10.30822/arteks.v3i2.60.

Supiyati, Sri, Farida Hanum, and Jailani Jailani. 2019. 'Ethnomathematics in Sasaknese Architecture'. Journal on Mathematics Education $\quad 10 \quad$ (1): $47-58$. https://doi.org/10.22342/jme.10.1.5383.4758.

Sutardi, Sri Rulliaty. 2015. Informasi Sifat Dasar Dan Kemungkinan Penggunaan 10 Jenis Bambu. Edited by Pusat Penelitian dan Pengembangan Hasil Hutan (Indonesia). Seri Paket. Jakarta: Pusat Penelitian dan Pengembangan Hasil Hutan, Badan Penelitian, Pengembangan dan Inovasi, Kementerian Lingkungan Hidup dan Kehutanan.

Tirtosastro, Samsuri, and A.S. Murdiyati. 2011. 'Pengolahan Daun Tembakau Dan Dampaknya Terhadap Lingkungan'. Buletin Tanaman Tembakau, Serat \& Minyak Industri 3 (2): 80. https://doi.org/10.21082/bultas.v3n2.2011.80 $-88$.

Titien Saraswati. 2008. 'Vernakularitas Los, Bangunan Pengering Tembakau Di Kabupaten Klaten, Jawa Tengah'. DIMENSI (Jurnal Teknik Arsitektur) 36 (1): 65-74. http://pus lit2.petra.ac.id/ejournal/index.php/a rs/article/view/16975. 
ARTEKS : Jurnal Teknik Arsitektur, Volume 6 Issue 1, April 2021

pISSN2541-0598; eISSN2541-1217 